Indah Nurhayati, Joko Sutrisno, Pungut, \& Budi Projo Sembodo : Arang Aktif Ampas Tebu sebagai Media Adsorbsi untuk Meningkatkan Kualitas Air Sumur Gali

\title{
ARANG AKTIF AMPAS TEBU SEBAGAI MEDIA ADSORPSI UNTUK MENINGKATKAN KUALITAS AIR SUMUR GALI
}

\author{
Indah Nurhayati $^{1)}$, Joko Sutrisno ${ }^{2)}$, Pungut ${ }^{3}$ ), dan Budi Prijo Sembodo ${ }^{4)}$ \\ 1), 2) \& 3) Program Studi Teknik Lingkungan, Fakultas Teknik Sipil dan Perencanaan \\ 4) Program Studi Teknik Elektro, Fakultas Teknologi Industri \\ Universitas PGRI Adi Buana (UNIPA) Surabaya \\ Email : indahtekling@yahoo.com
}

\begin{abstract}
Abstrak
Penelitian ini tentang pemanfaatan karbon aktif ampas tebu sebagai media adsorpsi untuk menurunkan kandungan zat besi dan kesadahan pada air sumur gali. Tujuan penelitian untuk menentukan suhu karbonasi dan konsentrasi $\mathrm{CaCO}_{3}$ yang paling optimum untuk pembuatan karbon aktif serta mengkaji efektifitasnya dalam menurunkan kadar logam Fe dan kesadahan. Penelitian ini terdiri atas dua tahap, tahap pertama menentukan kondisi optimum karbon aktif berdasarkan SNI 06-3730-1995 yang didasarkan pada suhu karbonasi dan konsentrasi $\mathrm{CaCO}_{3}$, tahap kedua penggunaan karbon aktif dalam penyerapan logam Fe dan kesadahan berdasarkan ketinggian media. Pengukuran kadar $\mathrm{Fe}^{3+}$ menggunakan spektrofotometer, sedangkan pengukuran kesadahan dengan menggunakan titrimeteri EDTA. Hasil penelitian menunjukkan konsentrasi $\mathrm{CaCO}_{3}$ 5,5.10 $0^{-5} \mathrm{M}$ dan suhu karbonasi $350^{\circ} \mathrm{C}$ paling optimum untuk menghasilkan karbon aktif paling sesusai SNI 06-3730-1995. Serapan optimum pada waktu operasi 2 jam pada media karbon aktif ampas tebu dengan tinggi $60 \mathrm{~cm}$ dapat menurunkan Fe sebesar 88\% dan kesadahan $60 \%$.
\end{abstract}

Kata Kunci : Adsorpsi, Ampas Tebu, Besi, Karbon Aktif, Kesadahan.

\begin{abstract}
This study on the use of activated carbon from bagasse as an adsorption medium to enhance iron content and hardness in dug wells. The aim of research to determine the most optimum of the carbonation temperature and concentration $\mathrm{CaCO} 3$ of to produce activated carabon and their effectiveness to adsorb the Fe and hardness and in water treatment dug wells. This study consisted of two stages, the first stage of determining the optimum conditions base on SNI 063730-1995 there was temperature, concentration of CaCO3. The second stage of the use of activated carbon in to enhance consentrationof Fe and hardness by adsorption based on height media activated carbon. Measurements of $F e$ using a spectrophotometer,hardness using titrimteri EDTA. The research result is a concentration of $\mathrm{CaCO3} 5,5.10^{-5} \mathrm{M}$ and a temperature of $350{ }^{\circ} \mathrm{C}$ most optimum carbonation base on SNI 06-3730-1995. In 2 hours operating time and media height of $60 \mathrm{~cm}$ optimum adsorption the Fe content can be lowered by $88 \%$ and hardness by $60 \%$.
\end{abstract}

Keywords: Adsorption, Bagasse, Iron, Activated Carbon, Hardness. 
Indah Nurhayati, Joko Sutrisno, Pungut, \& Budi Projo Sembodo : Arang Aktif Ampas Tebu sebagai Media Adsorbsi untuk Meningkatkan Kualitas Air Sumur Gali

\section{PENDAHULUAN}

Air tanah merupakan sumber air yang banyak digunakan dalam aktivitas domestik terutama sebagai air bersih. Perembesan air tanah melewati bebatuan mineral ketika merembes pada lapisan kulit bumi sehingga banyak ion logam yang terbawa. Air sumur adalah air tanah yang sebagaian besar kurang layak digunakan tanpa melalui pengolahan terlebih dahulu karena mengandung logam Besi (Fe), Mangan (Mn), Kalsium (Ca) dan Magnesium (Mg).

Kandungan $\mathrm{Fe}$ dan $\mathrm{Mn}$ dalam tubuh manusia dibatasi, logam ini bersifat akumulatif terutama pada organ penyaringan sehingga dapat mengganggu fungsi fisiologis, disamping itu logam $\mathrm{Fe}$ dan $\mathrm{Mn}$ dapat menimbulkan bau yang kurang sedap, menyebabkan warna kuning pada dinding bak penampung air bersih/kamar mandi serta menyebabkan bercak-bercak kuning pada pakaian.

Kandungan logam $\mathrm{Ca}$ dan $\mathrm{Mg}$ dalam air tanah mengubah sifatnya menjadi sadah. Air sadah kurang baik digunakan untuk kegiatan yang menggunakan sabun, karena logam $\mathrm{Ca}$ dan $\mathrm{Mg}$ bereaksi lebih dahulu dengan logam $\mathrm{Na}$ dalam sabun, sehingga terbentuklah senyawa-senyawa kalsium dan magnesium relative lebih sukar larut dalam air sehingga berakibat proses pencucian tidak berlangsung secara optimal.

Kualitas air bersih diatur dalam PERMENKES No.416/Menkes/Per/IX/1990 tentang standart kualitas air bersih, syarat untuk kandungan parameter logam $\mathrm{Fe}$ tidak boleh melebihi dari 1,0 mg/l, sedangkan $\mathrm{Mn} \leq$ $0,5 \mathrm{mg} / \mathrm{l}$ dan untuk kesadahan adalah $\leq 500$ $\mathrm{mg} / \mathrm{l}$. Metode yang umum digunakan untuk menurunkan kandungan $\mathrm{Fe}$ dan $\mathrm{Mn}$ dengan cara oksidasi yakni dilakukan kontak dengan udara sehingga logam mengendap dalam bentuk $\mathrm{Fe}(\mathrm{OH})_{2}$ dan $\mathrm{Mn}(\mathrm{OH})_{2}$, sedangkan metode lain yang digunakan dengan adsorpsi. Adsorpsi dapat digunakan untuk menurunkan kandungan logam dalam badan air.

Ampas tebu mampu menyerap ion $\mathrm{Pb}$ dan $\mathrm{Cu}$ sampai di atas $90 \%$ (Indah dan Joko :2013), logam-logam itu dalam sistem periodik unsur termasuk unsur logam golongan B sama dengan Fe dan Mn. Unsurunsur pada golongan yang sama memiliki sifat fisika maupun kimia yang hampir sama dengan demikian dapat diperkirakan bahwa $\mathrm{Fe}$ dan Mn mampu diserap oleh ampas tebu seperti $\mathrm{Pb}$ dan $\mathrm{Cu}$. Arang aktif dari ampas tebu yang diaktivasi dengan $\mathrm{H}_{3} \mathrm{PO}_{4} \quad 10 \%$ dapat digunakan sebagai adsorben pada pemurnian minyak goreng bekas, dengan mengikat asam lemak bebas sebesar 49,7\%. Arang ampas tebu yang diaktifasi menggunakan $\mathrm{HCl} 0,1 \mathrm{M}$ dapat menghasilkan arang aktif yang memenuhi SNI 06-3730-1995 (Asbahani, 2013).

\section{Karbon Aktif}

Karbon aktif adalah karbon yang telah diproses dengan cara diaktivasikan sehingga memiliki pori dengan luas permukaan yang sangat besar sehingga mampu meningkatkan daya adsorpsinya. Karbon aktif merupakan material yang memiliki diameter pori dengan ukuran skala molekul (nanometer) yang memiliki gaya Van derWaals yang kuat (Arfan, 2006). Karbon aktif (activated carbon) merupakan adsorben yang banyak digunakan pada pengolahan air, maupun pengolahan air limbah karena memilki kemampuan untuk menyerap senyawa organik dan anorganik.

Ampas tebu merupakan salah satu bahan yang cukup potensial dikembangkan sebagai karbon aktif karena ketersediaannya yang melimpah dan nilai ekonominya belum tinggi. Ampas tebu dapat diperoleh dari industri yang menggunakan tebu sebagai bahan baku yakni: pabrik pabrik gula yang tersebar di Pulau Jawa maupun di luar Pulau Jawa, usaha kecil berupa pembuatan gula merah disamping itu sekarang tumbuh usuha mikro yang berbahan baku tebu misalnya minuman es tebu.

Pada saat ini pemanfaatan ampas tebu sebagaian besar digunakan sebagai bahan bakar tambahan pada boiler, media tanam, bahan tambahan pupuk dan yang tidak termanfaatkan dibuang tanpa mengalami pengolahan sehingga menyebabkan pencemaran lingkungan yang pada akhirnya menyebabkan lingkungan menjadi tidak sehat serta berkurang nilai estetikanya. Berdasarkan paparan tersebut diperlukan solusi untuk menangani masalah ampas tebu dengan memanfaatkan ampas tebu dibuat menjadi karbon aktif, sehingga dapat mempunyai nilai tambah dan meningkatkan daya dukung lingkungan.

Karbon aktif berupa karbon amorf terdiri dari karbon bebas serta 
Indah Nurhayati, Joko Sutrisno, Pungut, \& Budi Projo Sembodo : Arang Aktif Ampas Tebu sebagai Media Adsorbsi untuk Meningkatkan Kualitas Air Sumur Gali

mempunyai kemampuan daya serap yang baik yang dapat digunakan sebagai bahan pemucat (penghilang zat warna), penyerap gas, penyerap logam, bahan organik maupun non organik yang dikenal dengan istilah adsorben (Rahayu, 2004 dalam Asbahani, 2013).

Bahan baku untuk pembuatan arang aktif dapat berasal dari hewan, tumbuhtumbuhan, limbah ataupun mineral yang mengandung karbon. Bahan baku tersebut antara lain tulang, sekam padi, tongkol jagung, tempurung kelapa, sabut kelapa, cangkang kelapa sawit, cangkang kopi, cangkang kemiri, ampas tebu, kulit durian, serbuk gergaji, kayu keras, kayu campuran, kayu lunak, kayu jati, kayu karet dan sebagainya (Siringgo- Ringgo, 2013). Pembuatan karbon aktif berlangsung tiga tahap yaitu proses dehidrasi, proses karbonisasi dan proses aktivasi. Sedangkan pemilihan bahan baku untuk pembuatan karbon aktif ditentukan berdasarkan besarnya kandungan karbon pada bahan.

Di Indonesia telah membuat standar mutu karbon aktif menurut BSN (Badan Standarisasi Nasional) yakni SNI 06-37301995, seperti pada tabel 1 di bawah ini :

Tabel 1. Standar Kualitas Karbon Aktif (BSN :SNI 06-3730-1995)

\begin{tabular}{lll}
\hline \multicolumn{1}{c}{ Uraian } & \multicolumn{2}{c}{ Prasyarat kualitas(\%) } \\
\cline { 2 - 3 } & \multicolumn{1}{c}{ Butiran } & \multicolumn{1}{c}{ Serbuk } \\
\hline Bagian yang hilang pada pemanasan $950^{\circ} \mathrm{C}$ & Maks. 15 & Maks. 25 \\
Konsentrasi air & Maks. 4,5 & Maks. 15 \\
Konsentras iabu & Maks. 2,5 & Maks. 10 \\
Karbonaktif murni & Min.80 & Min.65 \\
Daya serap terhadap Larutan $\mathrm{I}_{2}$ & Min.20 & Min.20 \\
\hline
\end{tabular}

Proses Pembuatan Karbon Aktif

Secara garis besar ada 3 tahap pembuatan karbon aktif, yaitu:

a. Proses Dehidrasi

Proses dehidrasi adalah proses penghilangan air pada bahan baku melalui reaksi kimia.

b. Proses karbonasi

Proses karbonasi adalah proses pembakaran bahan baku dengan menggunakan udara terbatas dengan temperature udara antara $300{ }^{\circ} \mathrm{C}$ sampai $900{ }^{\circ}$ C. Proses ini menyebabkan penguraian senyawa organik yang menyusun struktur bahan membentuk metanol, uap asam asetat, tar dan hidrokarbon. Material padat yang tertinggal setelah proses karbonisasi adalah karbon dalam bentuk arang dengan permukaan spesifik yang sempit.

\section{c. ProsesAktivasi}

Prosesaktivasi dibedakan menjadi 2 bagian, yaitu:

\section{Proses Aktivasi Termal}

Proses aktivasi termal umumnya melibatkan gas pengoksidasi seperti oksida oleh udara pada temperatur rendah, uap $\mathrm{CO}_{2}$ atau aliran gas pada temperatur tinggi.

2. Proses Aktivasi Kimia

Proses aktivasi kimia merujuk pada pelibatan bahan-bahan kimia atau reagen pengaktif. Bahan kimia yang dapat digunakan sebagai pengaktif diantaranya $\mathrm{CaCl}_{2}, \mathrm{CaCO}_{3}, \mathrm{NaCl}$, $\mathrm{MgCl}_{2}, \mathrm{HCl}, \mathrm{H}_{3} \mathrm{PO}_{4}, \mathrm{ZnCl}, \mathrm{HNO}_{3}$

\section{Karbon aktif dari Ampas Tebu}

Ampas tebu (Bagasse) adalah bahan sisa berserat dari batang tebu yang telah mengalami ekstraksi nira dan tidak tahan disimpan karena mudah terserang jamur. Ampas tebu kebanyakan digunakan sebagai bahan bakar untuk menghasilkan energy/panas sebagai bahan bakar ketel uap (Boiler) pada pabrik gula. Menurut Badan peneliti dan pengembangan PT Gula Putih Mataram tahun 2002, ampas tebu mengandung bahan organik sekitar 90\%, unsur hara $\mathrm{N}(0,3 \%), \mathrm{P}_{2} \mathrm{O}_{5}$ $(0,02 \%)$.

Ampas tebu dapat digunakan sebagai adsorben, seperti yang dikemukakan oleh Indah (2013) efisiensi penyerapan logam $\mathrm{Cu}$ dengan adsorben ampas tebu pada $\mathrm{pH} 6,51$ sebesar 94,3\%. Pada laju aliran $20 \mathrm{ml} / \mathrm{menit}$ 
Indah Nurhayati, Joko Sutrisno, Pungut, \& Budi Projo Sembodo : Arang Aktif Ampas Tebu sebagai Media Adsorbsi untuk Meningkatkan Kualitas Air Sumur Gali

ampas tebu dapat menyerap logam berat $\mathrm{Pb}$ sebesar 294 ppm dengan efisiensi $90 \%$.

Suhendarwati, dkk. Menyatakan bahwa arang aktif ampas tebu dengan aktifasi menggunakan $\mathrm{KOH} 5 \mathrm{M}$, diperoleh arang aktif yang mendekati standart arang aktif. Hasil penelitian (Sudibandriyo, 2011) menunjukkan bahwa luas permukaan arang aktif ampas tebu tertinggi sebesar 938,2 $\mathrm{m}^{2} / \mathrm{g}$ diperoleh dengan diperoleh dengan cara aktivasi menggunakan $\mathrm{KOH}$ dengan rasio massa aktivator/massa arang 3/1 dan karbonisasi dengan suhu $400^{\circ} \mathrm{C}$.

Surest, Azhary H.dkk. menyatakan pembuatan arang aktif ampas tebu dengan variabel jenis zat aktivator $(\mathrm{HCl}, \mathrm{NaOH}$, dan $\mathrm{CaCl}_{2}$ ), lamanya waktu aktivasi (24 jam, 22 jam, $20 \mathrm{jam})$, dan suhu karbonisasi $\left(300^{\circ} \mathrm{C}\right.$, $400^{\circ} \mathrm{C}$ dan $500^{\circ} \mathrm{C}$ ). Karbon aktif terbaik diperoleh dari pada suhu karbonisasi $500^{\circ} \mathrm{C}$, dengan menggunakan aktivator $\mathrm{HCl}$, lama aktivasi 24 jam

\section{Besi dan Kesadahan Dalam Air}

Kesadahan dinyatakan dalam $m g / l$ sebagai $\mathrm{CaCO}_{3}$ (kalsium karbonat) karena pada umumnya kesadahan ini dievaluasi pada kondisi konsentrasi ion kalsium $\left(\mathrm{Ca}^{2+}\right)$ dan magnesium $\left(\mathrm{Mg}^{2+}\right)$ yang merupakan ion utama penyebab kesadahan diturunkan dengan cara diendapkan dalam bentuk kalsium karbonat $\left(\mathrm{CaCO}_{3}\right)$. Kesadahan total dapat didefinisikan sebagai jumlah kesadahan kalsium dan kesadahan magnesium.

Air sadah dapat menyebabkan kerugian berupa gangguan dan atau kerusakan baik teknis maupun terhadap kesehatan manusia. Kesadahan air dapat menurunkan efisiensi dari penggunaan sabun. menyebabkan noda pada bahan pecah belah dan bahan flat, menyebabkan bahan linen berubah pucat, menyumbat semburan pembilas dan saluran air, Residu kesadahan Air dapat melapisi elemen pemanas dan menurunkan efisiensi panas dan dapat menciptakan buih logam pada kamar mandi shower dan bathtubs.

Beberapa studi mengindikasikan hubungan antara konsentrasi kesadahan terutama kalsium dan magnesium dengan penyakit kardiovaskuler. Mandi dengan sabun pada air sadah akan meninggalkan lapisan dadih sabun yang lengket pada lapisan kulit. Lapisan ini dapat menghalangi pembersihan terhadap tanah dan bakteri. Dadih sabun mencampuri kulit kembali sampai normal, kondisi asam rendah dan dapat menjadi iritasi. Mencuci rambut dengan air sadah dapat mengeraskan permukaan rambut karena tertutup oleh dadih yang membuat rambut rapuh, mudah kotor, sulit diatur, dan tidak berkilau sehingga diperlukan sampo berlebih. Pencucian dengan air lunak membuat bersih sepenuhnya, lembut, terlihat alami dan mudah diatur.

Unsur besi dalam air diperlukan untuk memenuhi kebutuhan tubuh merupakan unsur penting dan berguna untuk metabolisme tubuh diperlukan besin 7-35 mg/hari oleh tubuh. Zat besi dalam jumlah kecil dibutuhkan oleh tubuh untuk pembentukan sel-sel darah merah yang dapat diperoleh tidak hanya dari, tetapi dalam dosis besar dapat merusak dinding usus. Debu Fe juga dapat diakumulasi di dalam alveoli dan menyebabkan berkurangnya fungsi paruparu.

Konsentrasi besi yang tinggi dapat dirasakan dan dapat menodai kain dan perkakas dapur. Besi adalah elemen kimiawi yang dapat ditemukan hamper di setiaptempat dibumi pada semua lapisan geologis dan badan air. Besi dalam air dapat berbentuk Fe(II) dan $\mathrm{Fe}(\mathrm{III})$ terlarut. $\mathrm{Fe}$ (II) terlarut dapat tergabung dengan zat organik membentuk suatu senyawa kompleks (Asbahani, 2013).

Konsentrasi besi lebih besar dari 0,3 $\mathrm{mg} / \mathrm{l}$ dapat menimbulkan warna kuning pad aair,member rasa tidak enak, pengendapan pada dinding pipa, pertum- buhan bakteri besi, menyebabkan kekeruhan pada air (Asbahani, 2013).

Kadar besi dapat dikurangi/dihilangkan secara fisika, kimia, biologi maupun kombinasi dari metode tersebut. Metode fisika dapat dilakukan dengan cara adsorpsi, aerasi, presipitasi, elektrolitik, pertukaran ion(ionexchange), adsorbs dan sebagainya. Metode kimia dapat dilakukan dengan pembubuhan senyawa khlor, permanganat, kapur-soda, ozon, poliphosphat, koagulan, flokulan dll. Metode biologi dapat dilakukan denganc aramenggunakan mikroorganisme akteri besi yang mampu mengoksidasi senyawa besi dan mangan(Asbahani 2013). 
METODE

Populasi dalam penelitian ini adalah air sumur gali yang mengandung logam berat $\mathrm{Fe}^{2+}$ dan kesadahan di atas baku mutu air bersih sesuai dengan PERMENKES No.416/MEN.KES/PER/IX/1990 tentang syarat-syarat dan pengawasan kualitas air. Sebagai sampel adalah sampel buatan yakni larutan $\mathrm{FeSO}_{4}$, dan $\mathrm{CaCO}_{3}$ dengan kadar $\mathrm{Fe}$ 4,24 ppm dan kesadahan $1428 \mathrm{mg} / \mathrm{L}$.

\section{Variabel Penelitian}

Variabel bebas dalam penelitian adalah suhu karbonasi pembuatan arang aktif dari ampas tebu, yaitu suhu $300^{\circ} \mathrm{C}, 350^{\circ} \mathrm{C}$, $400^{\circ} \mathrm{C}, 450^{\circ} \mathrm{C}$ dan $500^{\circ} \mathrm{C}$, konsentrasi $\mathrm{CaCO}_{3}$ yang digunakan untuk aktivasi arang ampas tebu, yaitu $5,5.10^{-5} \mathrm{M}$ dan $2,75.10^{-5} \mathrm{M}$ dan ketinggian media adsorpsi ampas tebu yakni $30 \mathrm{~cm}$ dan $60 \mathrm{~cm}$, sedangkan variabel terikat kualitas karbon aktif sesuai dengan SNI dengan SNI 06-3730-1995 untuk pembuatan karbon aktif dan konsentrasi ion logam Fe dan kesadahan total untuk adsorpsi.

\section{Langkah Penelitian}

Langkah-langkah penelitian adalah sebagai berikut:

1. Pembuatan arang aktif ampas tebu

a Mengeringkan ampas tebu dengan matahari langsung hingga kadar air yang dikandung rendah (kering). Kemudian ampas tebu dipotongpotong dengan ukuran $5 \mathrm{~mm}$.

b. Pada proses karbonasi ampas tebu dilakukan dengan cara membakar ampas tebu dalam furnace tubular elama 30 menit pada suhu yang divariasikan $\left(300^{\circ} \mathrm{C}, 350^{\circ} \mathrm{C}, 400^{\circ} \mathrm{C}\right.$, $450^{\circ} \mathrm{C}, 500^{\circ} \mathrm{C}$.)

c. Proses aktivasi kimia dilakukan dengan menggunakan larutan $\mathrm{CaCO}_{3}$ dengan konsentrasi $5,5.10^{-5} \mathrm{M}$ dan $2,75.10^{-5} \mathrm{M}$.

d. Proses aktivasi ini dilakukan dengan cara mengaduk menggunakan magnetic strirrer selama 4 jam pada suhu dijaga $80^{\circ} \mathrm{C}$. Setelah itu didiamkan selama 24 jam.

e. Menyaring arang ampas tebu dengan kertas saring, dan mencuci dengan aquades hingga $\mathrm{pH}$ 7. Sampel dikeringkan dalam oven dari suhu

kamar sampai suhu $150^{\circ} \mathrm{C}$ selama 2 jam.

f. Menganalisis kualitas karbon aktif ampas tebu untuk kualitas air sumur gali.

1) Bagian yang hilang pada pemanasan $950^{\circ} \mathrm{C}$

Karbon aktif dipanaskan sampai suhu $950^{\circ} \mathrm{C}$ dalam furnace. Setelah suhu tercapai, karbon dibiarkan dingin dalam furnace dalam kondisi tidak berhubungan dengan udara luar. Setelah dingin dimasukkan kedalam desikator dan ditimbang. Untuk menghitung bagian yang hilang pada pemanasan $950^{\circ} \mathrm{C}$ menggunakan rumus sebagai berikut:

$$
\% \text { Volatile matter }=\frac{a-b}{a} \times 100 \%
$$

$\mathrm{a}=$ berat karbon aktif mula-mula (gram)

$\mathrm{b}=$ berat karbon akhir

\section{2) Kadar air}

Karbon aktif ditimbang seberat 1 gram dan dimasukkan ke dalam kurs porselin yang telah dikeringkan, kemudian dimasukkan ke dalam oven pada suhu $115^{\circ} \mathrm{C}$ selama 3 jam, selanjutnya sampel karbonaktif didinginkan dalam desikator dan ditimbang. Kadar air dapat dihitung dengan persamaan berikut:

$$
\text { Volatile matter }=\frac{a-b}{a} \times 100 \%
$$

$\mathrm{a}=$ berat karbon aktif mula- mula (gram)

$\mathrm{b}=$ berat karbon aktif setelah dikeringkan (gram)

3) Kadar abu

Karbonaktif ditimbang seberat 1 gram dimasukkan kedalam kurs porselin yang telah diketahui beratnya. Lalu diabukan dalam furnace secara perlahan setelah semua karbon hilang. Nyala diperbesar pada suhu $800^{\circ} \mathrm{C}$ selama 2 jam. Bila seluruh karbon telah menjadi abu, dinginkan dalam desikator lalu ditimbang hingga diperoleh bobot tetapnya. Untuk menghitung konsentrasi abu menggunakan rumus sebagai berikut: 
Indah Nurhayati, Joko Sutrisno, Pungut, \& Budi Projo Sembodo : Arang Aktif Ampas Tebu sebagai Media Adsorbsi untuk Meningkatkan Kualitas Air Sumur Gali

Kadar abu $=\frac{\text { berat abu }}{\text { berat } \operatorname{sampl}} \times 100 \%$

4) Daya serap terhadap $I_{2}$

a) Karbon aktif ditimbang sebanyak 0,5 gram dan dicampurkan dengan $50 \mathrm{ml}$ larutan Iodium $0,1 \mathrm{~N}$, kemudian dikocok dengan alat pengocok selama 15 menit.

b) Setelah itu sampel disentrifuge sampai karbonnya turun.

c) Kemudian diambil $10 \mathrm{ml}$ larutan sampel dan dititrasi dengan larutan Natrium Tiosulfat $0,1 \mathrm{~N}$.

d) Jika warna kuning pada larutan mulai samar, kedalam larutan tersebut ditambahkan larutan amilum $1 \%$ sebagai indikator sehingga berwarna biru tua.

e) Larutan dititrasi kembali sampai warna biru tua berubah menjadi warna bening.

f) Menghitung daya serap $\mathrm{I}_{2}$ dengan rumus sebagai berikut. $\mathrm{I}_{2}(\mathrm{mg} / \mathrm{g})=\frac{\left(10-\frac{V_{x N}}{\mathrm{Q}_{1}}\right) \times 12,69 \times \mathrm{s}}{\mathrm{W}}$ $\mathrm{V}=$ volume natrium thio sulfat

$\mathrm{N}=$ normalitas natrium thiosulfat

$12,69=\mathrm{jml} \mathrm{I}_{2}$ sesuai dengan $1 \mathrm{ml}$ natrium thiosulfat $\mathrm{W}=$ berat sampel

2. Karbon aktif dengan kualitas terbaik digunakan sebagai media adsorpsi untuk menurunkan Fe dan kesadahan.
Adsorpsi dengan adsorben arang aktif ampas tebu

a. Menyusun media adsorpsi yang terdiri dari pasir, arang aktif ampas tebu dan kerikil

b. Mengisi kolom adsorpsi dengan air suling terlebih dahulu untuk membasahi media penyerap.

c. Sampel air buatan dimasukkan ke dalam bak penampung tandon.

d. Dengan menggunakan pompa air dari tandon dialirkan ke bak pengatur debit.

e. Mengukur debit sampai diperoleh debit konstan

f. Air yang keluar dari output kolom diukur konsentrasi logamnya dan kesadahannya.

g. Pengambilan sampel dilakukan setiap 15 menit dengan operasi adsorpsi selama 2 jam

\section{Metode Analisis Data}

Data pengukuran parameter karbon aktif didasarkan/dibandingkan dengan Standar Kualitas Karbon Aktif SNI 06-3730-1995) ,jumlah parameter yang memenuhi syarat dijadikan acuan dalam menentukan kualitas karbon aktif. Data hasil penelitian bedasarkan ketinggian adsorben berupa parameter besi dan kesadahan dilakukan analisis secara deskriptif disajikan dalam bentuk tabel dan grafik.

HASIL DAN PEMBAHASAN

Pengaruh Suhu Karbonasi dan Konsentrasi $\mathrm{CaCO}_{3}$ terhadap Kualitas Arang Aktif

Kualitas arang aktif yang dihasilkan dari ampas tebu dengan aktivasi larutan $\mathrm{CaCO}_{3}$ dapat dilihat pada tabel 2 . 
Indah Nurhayati, Joko Sutrisno, Pungut, \& Budi Projo Sembodo : Arang Aktif Ampas Tebu sebagai Media Adsorbsi untuk Meningkatkan Kualitas Air Sumur Gali

Tabel 2. Kualitas Carbon Aktif Ampas Tebu

\begin{tabular}{|c|c|c|c|c|c|}
\hline \multirow{2}{*}{$\begin{array}{c}\text { SUHU } \\
\text { KARBONASI }\end{array}$} & \multirow[t]{2}{*}{ KUALITAS ARANG } & \multicolumn{2}{|c|}{$\begin{array}{c}\mathrm{CaCO}_{3} \\
\left(5,5 \cdot 10^{-5} \mathrm{M}\right)\end{array}$} & \multicolumn{2}{|c|}{$\begin{array}{c}\mathrm{CaCO}_{3} \\
\left(2.7,5.10^{-5} \mathrm{M}\right)\end{array}$} \\
\hline & & & Ket & & Ket \\
\hline \multirow[t]{4}{*}{$300^{\circ} \mathrm{C}$} & Bagian yang hilang pada pemanasan $950^{\circ} \mathrm{C}(\%)$ & 97 & TM & 97 & TM \\
\hline & Kadar abu (\%) & 86 & TM & 91 & TM \\
\hline & Kadar air $(\%)$ & 4 & M & 5 & $\mathrm{M}$ \\
\hline & Daya serap $I_{2}(\mathrm{mg} / \mathrm{g})$ & 380 & M & 279 & $\mathrm{M}$ \\
\hline \multirow[t]{4}{*}{$350^{\circ} \mathrm{C}$} & Bagian yang hilang pada pemanasan $950^{\circ} \mathrm{C}(\%)$ & 94 & $\mathrm{TM}$ & 99 & $\mathrm{TM}$ \\
\hline & Kadar abu (\%) & 71 & TM & 80 & TM \\
\hline & Kadar air $(\%)$ & 5 & M & 5 & M \\
\hline & Daya serap $\mathrm{I}_{2}(\mathrm{mg} / \mathrm{g})$ & 432 & M & 380 & M \\
\hline \multirow[t]{4}{*}{$400^{\circ} \mathrm{C}$} & Bagian yang hilang pada pemanasan $950^{\circ} \mathrm{C}(\%)$ & 92 & $\mathrm{TM}$ & 96 & $\mathrm{TM}$ \\
\hline & Kadar abu $(\%)$ & 66 & $\mathrm{TM}$ & 75 & $\mathrm{TM}$ \\
\hline & Kadar air $(\%)$ & 5 & M & 5 & M \\
\hline & Daya serap $\mathrm{I}_{2}(\mathrm{mg} / \mathrm{g})$ & 368 & M & 253 & M \\
\hline \multirow[t]{4}{*}{$450^{\circ} \mathrm{C}$} & Bagian yang hilang pada pemanasan $950^{\circ} \mathrm{C}(\%)$ & 93 & $\mathrm{TM}$ & 99 & $\mathrm{TM}$ \\
\hline & Kadar abu (\%) & 67 & TM & 73 & $\mathrm{TM}$ \\
\hline & Kadar air $(\%)$ & 5 & M & 6 & M \\
\hline & Daya serap $\mathrm{I}_{2}(\mathrm{mg} / \mathrm{g})$ & 298 & M & 253 & M \\
\hline \multirow[t]{4}{*}{$500^{\circ} \mathrm{C}$} & Bagian yang hilang pada pemanasan $950^{\circ} \mathrm{C}(\%)$ & 98 & $\mathrm{TM}$ & 98 & $\mathrm{TM}$ \\
\hline & Kadar abu (\%) & 50 & TM & 69 & TM \\
\hline & Kadar air $(\%)$ & 5 & M & 6 & M \\
\hline & Daya serap $\mathrm{I}_{2}(\mathrm{mg} / \mathrm{g})$ & 285 & M & 247 & M \\
\hline
\end{tabular}

Keterangan :

M : Memenuhi SNI 06-3730-1995; TM : Tidak memenuhi SNI 06-3730-1995

Uji Kualitas daya serap terhadap $\mathbf{I}_{2}$

Uji kualitas daya serap terhadap iodin bertujuan untuk mengetahui kemampuan adsorpsi dalam mengadsorbsi larutan yang berbau. Daya serap karbon aktif terhadap iodida adalah jumlah miligram iodin yang diadsorpsi oleh satu gram karbon aktif. Pengaruh suhu karbonasi dan konsentrasi $\mathrm{CaCO}_{3}$ terhadap daya serap $\mathrm{I}_{2}$ dapat dilihat pada gambar 1 .

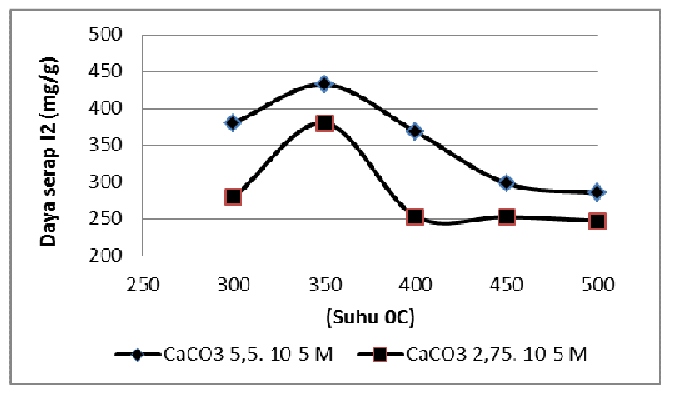

Gambar 1. Konsentrasi $\mathrm{CaCO}_{3}$ Terhadap Daya Serap $\mathrm{I}_{2}$
Dari gambar 1 dapat dilihat bahwa suhu karbonasi terhadap ampas tebu berpengaruh terhadap daya serap $\mathrm{I}_{2}$. Pada suhu $350^{\circ} \mathrm{C}$ dihasilkan karbon aktif yang mempunyai daya serap paling tinggi, hal ini disebabkan pada karena pada suhu dibawah $350^{\circ} \mathrm{C}$ ampas tebu belum mengalami karbonasi sempurna dan pada suhu karbonasi diatas $350^{\circ} \mathrm{C}$ daya serap $\mathrm{I}_{2}$ semakin menurun dikarenakan pada suhu tinggi carbon terbakar menjadi abu.

Konsentrasi $\mathrm{CaCO}_{3}$ juga berpengaruh terhadap daya serap $\mathrm{I}_{2}$, semakin tinggi konsentrasi $\mathrm{CaCO}_{3}$ semakin tinggi daya serap $\mathrm{I}_{2}$, hal ini dikarenakan penambahan konsentrasi senyawa pengaktivasi akan memudahkan senyawa-senyawa tar diikat keluar melewati pori-pori karbonaktif sehingga permukaan karbonaktif semakin lebar atau luas sehingga semakin besar pula daya serap karbonaktif tersebut.

Dengan adanya zat pengakivasi berfungsi sebagai reagen pengaktif dan zat ini 
akan mengaktifkan atom-atom karbon sehingga daya serapnya menjadi lebih baik. Zat aktivator bersifat mengikat air yang menyebabkan air yang terikat kuat pada pori- pori karbon yang tidak hilang pada saat karbonisasi menjadi lepas. Selanjutnya zat aktivator tersebut akan memasuki pori dan membuka permukaan arang yang tertutup. Dengan demikian pada saat dilakukan pemanasan,senyawa pengotoryang berada dalam pori menjadi lebih mudah terserap sehingga luas permukaan karbon aktif semakin besar dan meningkatkan daya serapnya.

Sesuai dengan standart kualitas karbon aktif sesuai SNI 06-3730-1995 daya serap $\mathrm{I}_{2}$ adalah minimal $20 \mathrm{mg} / \mathrm{g}$, dengan demikian karbon aktif ampas tebu dengan suhu karbonasi $350-500^{\circ} \mathrm{C}$ dan aktivasi selama 4 jam dengan suhu $80^{\circ} \mathrm{C}$ dihasilkan karbon aktiv yang memenuhi kualitas sesuai SNI 06-37301995 untuk parameter daya serap $I_{2}$.

\section{Kadar Air Karbon Aktif}

SNI 06-3730-1995 mensyaratkan kadar abu untuk karbon aktif serbuk maksimal $15 \%$. Karbon aktif ampas tebu dengan suhu karbonasi $350-500^{\circ} \mathrm{C}$ dan aktivasi selama 4 jam dengan suhu $80^{\circ} \mathrm{C}$ dihasilkan karbon aktif yang memenuhi kualitas kadar air. Kadar air yang tinggi berpengaruh terhadap daya serap adsorben.

Pengaruh suhu kabonasi dan konsentrasi $\mathrm{CaCO}_{3}$ terhadap kadar air dari karbon aktif ampas tebu dapat dilihat pada gambar 2. Dari gambar 2 menunjukkan bahwa suhu kabonasi dan konsentrasi $\mathrm{CaCO}_{3}$ tidak berpengaruh terhadap kadar air.

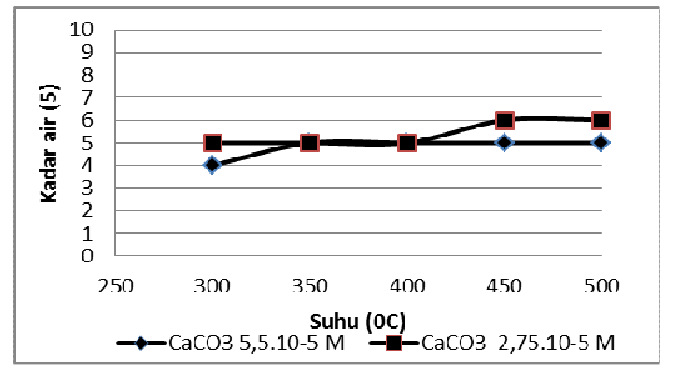

Gambar 2. Pengaruh Suhu Kabonasi dan Konsentrasi CaCO3Kadar Air

\section{Kadar Abu Karbon Aktif}

Kadar abu merupakan sisa mineral yang tertinggal setelah pembakaran pada suhu $500-800^{\circ} \mathrm{C}$. Karbon aktif ampas tebu dengan suhu karbonasi antara $300-500^{\circ} \mathrm{C}$ dan aktivasi menggunakan $\mathrm{CaCO}_{3}$ kadar abunya antara 50 \% - 91\%. Sesuai dengan SNI06-3730-1995 karbon aktiv minimal kadar abunya $10 \%$. Dengan demikian Karbon aktif ampas tebu dengan suhu karbonasi antara $300-500^{\circ} \mathrm{C}$ dan aktivasi menggunakan $\mathrm{CaCO}_{3}$ belum memenuhi standa mutu karbonaktif SNI063730-1995. Hasil karbon aktif yang belum memenuhi standar tersebut kemungkinan disebabkan kurang lama dan kurang tinggi suhu proses aktifasinya sehingga pori- pori belum mengembang dan belum dapat terbuka sempurna. Selain itu dapat juga dipengaruh ioleh kandungan karbon yang dimiliki ampas tebu rendah, sehingga sedikit karbon yang berhasil teraktivasi, serta adanya pengotor lain yang menyebabkan terbentuknya karbonaktif menjadi terhambat.

Dari gambar 3 terlihat bahwa suhu karbonasi dan konsentrasi $\mathrm{CaCO}_{3}$ berpengaruh terhadap kadar abu karbon aktif. Semakin tinggi konsentrasi semakin rendah kadar abunya dan semakin tinggi suhu karbonasi juga semakin rendah kadar abunya.

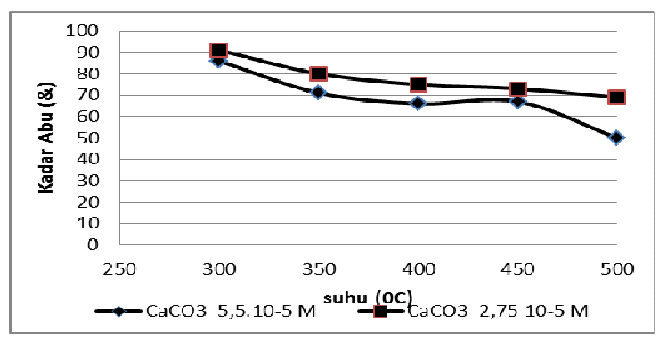

Gambar 3. Pengaruh Suhu Kabonasi dan Konsentrasi $\mathrm{CaCO} 3$ Kadar Abu

\section{Bagian Yang Hilang Pada Pemanasan $950^{\circ} \mathrm{C}$}

Uji bagian yang hilang pada pemanasan $950^{\circ} \mathrm{C}$ bertujuan untuk melihat seberapa besar bagian yang hilang dari karbon aktif apabila dilakukan pemanasan hingga $950^{\circ} \mathrm{C}$. Sesuai dengan SNI 06-3730-1995 karbon aktif minimal kadar bagian yang hilang pada pemanasan $950^{\circ} \mathrm{C}$ maksimal $25 \%$. Karbon aktif ampas tebu dengan suhu karbonasi antara 300 $500^{\circ} \mathrm{C}$ dan aktivasi menggunakan $\mathrm{CaCO} 3$ memiliki kadar bagian yang hilang pada pemanasan $950^{\circ} \mathrm{C}$ antara $92 \%$ - 99\%. Secara keseluruhan karbon aktif yang dihasilkan belum memenuhi standar karbon aktif sesuai SNI 063730-1995. Hal ini kemungkinan disebabkan tidak sempurnanya penguraian senyawa 
nonkarbon seperti $\mathrm{CO}_{2}, \mathrm{CO}$ dan $\mathrm{H}_{2}$.

Pengaruh suhu kabonasi dan

konsentrasi $\mathrm{CaCO}_{3}$ terhadap kadar bagian yang

hilang pada pemanasan $950^{\circ} \mathrm{C}$ karbon aktif ampas tebu dapat dilihat pada gambar 4 .

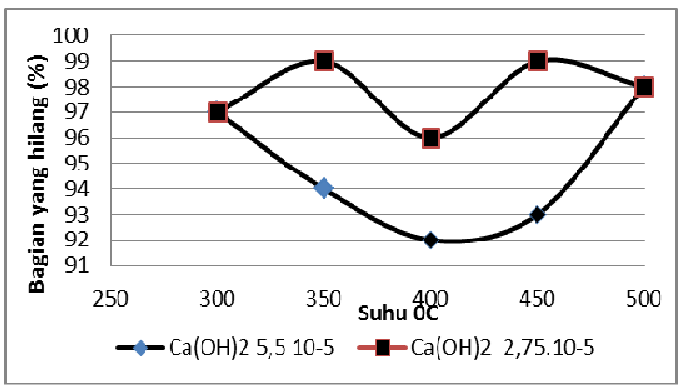

Gambar 4. Pengaruh Suhu Kabonasi dan Konsentrasi $\mathrm{CaCO}_{3}$ Terhadap Kadar Bagian Yang Hilang Pada Pemanasan $950^{\circ} \mathrm{C}$

Suhu karbonasi dan konsentrasi $\mathrm{CaCO}_{3}$ berpengaruh terhadap kualitas karbon aktif untuk parameter bagian yang hilang pada pemanasan $950^{\circ} \mathrm{C}$. Semakin pekat konsentrasi zat aktivator semakin kecil kadar bagian yang hilang pada pemanasan $950^{\circ} \mathrm{C}$. Dari suhu karbonasi antara $300-500^{\circ} \mathrm{C}$ didapatkan kadar bagian yang hilang pada pemanasan $950^{\circ} \mathrm{C}$ paling kecil pada suhu karbonasi $400^{\circ} \mathrm{C}$.

Pembuatan karbon aktif ampas tebu berdasarkan variasi suhu karbonasi dan konsentrasi $\mathrm{CaCO} 3$ sebagai bahan aktivasinya didapatkan karbon aktif yang paling baik sesuai SNI06-3730-1995 adalah karbon aktif pada suhu karbonasi $350^{\circ} \mathrm{C}$ dan diaktivasi menggunakan $\mathrm{CaCO}_{3}$ dengan konsentrasi 5,5. $10^{-5} \mathrm{M}$

\section{Pengaruh Ketinggian Karbon Aktif Terhadap Penurunan Fe dan Kesadahan}

Hasil analisis kadar $\mathrm{Fe}$ dan kesadahan dalam sampel air bersih setelah diadsorpsi menggunakan media pasir, karbon aktif dan kerikil disajikan dalam gambar 5 dan 6 .

Pengaruh ketinggian karbon aktif terhadap penurunan $\mathrm{Fe}$ dan kesadahan dapat dilihat pada gambar 5 dan 6 .

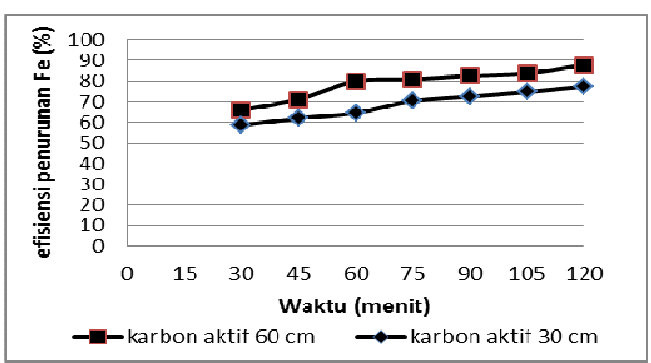

Gambar 5. Pengaruh Tinggi Media Terhadap Efisiensi Penurunan Fe

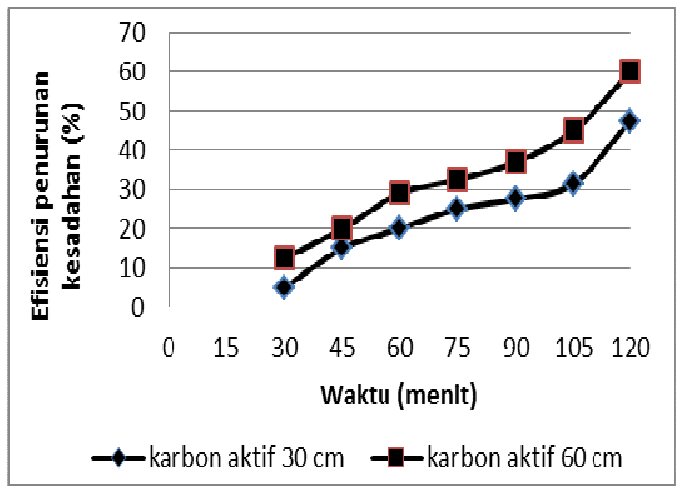

Gambar 6. Pengaruh Tinggi Media Terhadap Efisiensi Penurunan Kesadahan

Dari gambar 5 dan 6 terlihat bahwa tinggi media karbon aktif dalam proses adsorpsi berpengaruh terhadap efisiensi penurunan $\mathrm{Fe}$ dan kesadahan. Semakin tinggi media karbon aktif semakin tinggi efisiensi penurunan $\mathrm{Fe}$ dan kesadahan. Hal ini terjadi karena dengan semakin tinggi media berarti semakin bertambah jumlahkarbon aktif ampas tebu dan menyebabkan bertambahnya jumlah partikel dan luas permukaan material karbon ampas tebu, sehingga semakin bertambah besarnya daya serap terhadap $\mathrm{Fe}$ dan kesadahan.

Dalam waktu operasi adsorpsi selama 2 jam efisiensi penurunan $\mathrm{Fe}$ dan kesadahan masih mengalami kenaikan, hal ini menunjukan media karbon aktif belum mengalami kejenuhan. Efisiensi penurunan Fe lebih tinggi daripada efisiensi penurunan kesadahan, keadaan ini disebabkan $\mathrm{Fe}$ merupakan logam amfoter sehingga dapat terikat dalam keadaan asam ataupun basa, selain itu disebabkan $\mathrm{Fe}$ juga dapat berikatan kovalen koordinasi.

Kesadahan dalam air diidentikan dengan kadar Ca. Rendahnya penurunan $\mathrm{Ca}$ kemungkinan disebabkan karena proses aktivasi karbon ampas tebu ini menggunakan $\mathrm{CaCO}_{3}$ sehingga 
dalam proses adsorpsi karbon aktif kurang kuat mengikat $\mathrm{Ca}$, kemungkinan ada $\mathrm{Ca}$ yang terlepas pada saat adsorpsi.

\section{KESIMPULAN}

Dari penelitian ini dapat disimpulkan bahwa:

1. Konsentrasi $\mathrm{CaCO}_{3} \quad 5,5.10^{-5} \mathrm{M}$ adalah konsentrasi yang paling baik untuk menghasilkan karbon aktif ampas tebu dengan kualitas sesusai dengan SNI 063730-1995 terutama untuk parameter daya serap $\mathrm{I}_{2}$ dan kadar air

2. Suhu karbonasi ampas tebu $350^{\circ} \mathrm{C}$ adalah suhu yang paling baik untuk menghasilkan karbon aktif dari ampas tebu dengan kualitas sesusai dengan SNI06-3730- 1995terutama untuk parameter daya serap $\mathrm{I}_{2}$ dan kadar air

3. Selama waktu operasi 2 jam media karbon aktif ampas tebu dengan tinggi $60 \mathrm{~cm}$ dapat menurunkan $\mathrm{Fe}$ sebesar $88 \%$ dan kesadahan $60 \%$.

4. Ketinggian media karbon aktif ampas tebu berpengaruh terhadap efisiensi penurunan Fe dan kesadahan.

\section{Ucapan Terima Kasih}

Peneliti mengucapkan terima kasih kepada Lembaga Penelitian dan Pengabdian Pada Masyarakat (LPPM) Universitas PGRI Adi Buana (UNIPA) Surabaya yang telah membiayai penelitian ini melalui hibah Adi Buana.

\section{DAFTAR PUSTAKA}

Arfan Y. 2006. Pembuatan KarbonAktif Berbahan Dasar Batubara Dengan Perlakuan Aktivasi Terkontrol Serta Uji Kinerjanya. Depok: DepartemenTeknikKimiaFt-Ui.

Asbahani . 2013. Pemanfaatan Limbah Ampas Tebu Sebagai Karbon Aktif Untuk Menurunkan Kadar Besi Pada Air SumurJurnal Teknik Sipil Untan / Volume 13 Nomor 1 - Juni 2013.

Benny Syahputra, Hermin Poedjiastoeti,2012. Penurunan Fe Pada AirSumur Secara Pneumatic System, Http://Www.Journal.Unissula.Ac.Id >Home>Vol14,No ( 15 Juni 2013 )

Depkes Ri, 1992. Undang-Undang No.23 Th.1992 Tentang Kesehatan, Jakarta.

Depkesri, 1990. Peraturan Menkes Ri No.416/Menkes/Per/Ix/199Tentang Syarat-Syarat Dan Pengawasan Kualitas Air, Jakarta.

Ditjen Ppm Dan Plp, 1998. Pedoman Penyehatan Air, Depkes Ri, Jakarta.

Erlani, 2011. Variasi Luas Wilayah Cascade Terhadap PenurunanKadar Fe (Besi) Air, Http://Www.Sanitasi-Keslingmks-Biogspot.Com. (10 Juni 2013)

Farihah T. Dkk. 2013. Pengaruh Ukuran Arang Akti Ampas Tebu Sebagai Biomaterial Pretreatment Terhadap Karakteristik Biodiesel Minyak Jelantah. Jurnal Teknik Pomits Vol. 2, No. 2, Institut Teknologi Sepuluh Nopember Surabaya.

Hermana, J, Voijant B, Dan Samodra M.A (2001). Laboratorium Lingkungan, Jurusan Teknik Lingkungan FTSP ITS Surabaya.

Indah, N Dan Joko, S. 2013. Pemanfaatan Limbah Ampas Tebu Sebagai Penyerap Logam Berat Cu. Program Studi Teknik Lingkungan, FTSP Unipa, Surabaya.

Margono, 2010. Kridha Nirmala, POLTEKES Kemenkes Surabaya.

Notoatmodjo,S, 1993. Metodologi Penelitian Kesehatan, Rineka Cipta, Jakarta

Sanropie, Djoko Dan Mardjono, 1984. Penyediaan Air Bersih, Depkes Ri, Jakarta..

Siringo-Ringo, Berliana, Dkk. 2013. Arang Aktif.

Http://Www.Sharemyeyes.Com/2013/06/Arang-Aktif.Html Diakses 5 Mei 2014.

Suhendarwati, Et, All . Pengaruh Konsentrasi Larutan Kalium Hidroksida Pada Abu Dasar Ampas Tebu Teraktivasi. Jurnal Sumberdaya Alam \& Lingkungan. Fakultas Teknologi Pertanian, Universitas Brawijaya

Sudibandriyo, M, Dkk. 2011. Karakteristik Luas Permukaan Karbon Aktif Dari AmpasTebu Dengan Aktivasi Kimia. Jurnal Teknik Kimia Indonesia Vol. 10, No. 3, 2011, 149-156. UI Depok

Surest, Azhary H.Dkk. PembuatanKarbon Aktif Dari Cangkang Biji Ketapang. 